\title{
Proposed New Marketing Strategy to Increase Sales and Brand Consideration for Healthy Food Business (A Case of Miethy)
}

\author{
Delisa Julianita Putri
}

\section{ABSTRACT}

Covid-19 pandemic makes people are beginning to prevent of these dangerous diseases, such as exercise, mental health care, and consuming healthy foods. The high demand of people's awareness of healthy food has made the food and beverage sector business increase. Miethy also had a chance to offer a variety healthy food. But, Miethy had a $23 \%$ declined in sales after four months of launching and sales always below the target.

This paper research is to analyze Miethy's current condition, to find out what can be done to make sales increase, and what is the ideal marketing plan for Miethy's in the future. The qualitative method that used for internal and external analysis, there are STP analysis, 4P's marketing mix analysis, Five Porter's Forces, Competitive analysis, and Customer analysis. The problem was found that Miethy's marketing activities with Miethy STP was not suitable, and Miethy experienced in high competition compared to its competitors because of the company's lack of branding.

Based on the results of this research, Miethy is required to redesign a new marketing strategy. The new marketing strategy that becomes the final solution is the 4P's marketing mix. Miethy will arrange a "Healthy Noodle Snack" with three flavors (chicken curry, spicy, cheese) for a new product variant. New Miethy product sales will be placed in Bandung with an affordable price. And Miethy must also optimize digital marketing on social media and online marketplace for product promotion.

Submitted : December 28, 2022

Published : February 28, 2022

ISSN: 2507-1076

DOI: $10.24018 /$ ejbmr.2022.7.1.1226

Delisa Julianita Putri*

Bandung Institute of Technology,

Bandung, West Java, Indonesia

(e-mail: delisa_julianita@sbm-itb.ac.id)

Keywords: Covid-19, Healthy food, Marketing strategy, SWOT Analysis.

\section{INTRODUCTION}

Implementation of a healthy lifestyle is still very difficult for Indonesian people. The availability of healthy foods is hard to find and make such a challenge of maintaining a balanced diet and regular exercises. As a result, individuals are becoming increasingly disengaged from a healthy lifestyle.

According to data on Healthy Meals Among Indonesian Millennials in 2018, people are starting to realize that the health of the human body is very important to avoid various dangerous diseases coming, and people start their healthy lives starting with sorting out the food they will consume daily (Jakpat, 2018). Especially millennial ages (in range of 16 until 35 years old), are increasingly placing more importance on the nutritional content of the food they consume compared to the price and taste. That ages are still very productive and have a very long-life potential. Therefore, millenials have to balancing their daily life with consuming a healthy food.

The food and beverages business in Indonesia still a few who provided healthy food. It was because of the attraction of the people who still underestimate healthy food. Creating a healthy culinary business in Indonesia during and after the Covid-19 pandemic is a very good idea, because one of the preventive measures from Covid-19 according to the World Health Organization is consuming a lot of healthy food (WHO, 2020).

Seeing the condition of Indonesia, which is becoming more health-conscious, people are gradually changing their lifestyles and are prepared to spend more for assured and nutritious food quality. But nowadays the healthy food sector is becoming more commercially competitive. Therefore, this research will focus on to create the most suitable marketing strategy with the current condition of Miethy.

\section{BUSINESS ISSUE EXPLORATION}

Miethy is a food and beverages business originating from Bandung, Indonesia. Miethy was formed by six magister students in 2020. Having a different basic knowledge, they tried to unite the ideas and concepts from Miethy's business to change their lifestyle and the Indonesian people into a healthy lifestyle, especially during Covid-19 pandemic. According to the brand name, Miethy is "Healthy and Tasty Noodle", and the product is in the form of almond-based organic noodles. Miethy might be the public's choice for fulfilling the needs of a healthy lifestyle. But Miethy began 
to decline in sales and company performance four months after the product was launched.

According to sales data, Miethy's sales began to decline in the fourth month after its product launched, which is $23 \%$ declined. As long as this business is running, sales of Miethy's products are always below the sales target. And Miethy's team has made several process changes in noodle production, including trial and error several times. This makes Miethy's cash flow was uncontrollable. Therefore, Miethy had to analyze the business process and get a new strategy.

To overcome these problems, Miethy proposes a conceptual framework to analyzing the company with two analytical approaches: internal and external analysis. Internal analysis is carried out to assess the company's current position using Segmentation - Targeting Positioning Analysis, Marketing Mix 4P's Analysis. The external analysis is performed to compare, and find the solution by using Five Porters Forces, Customer Analysis, and Competitive Analysis.

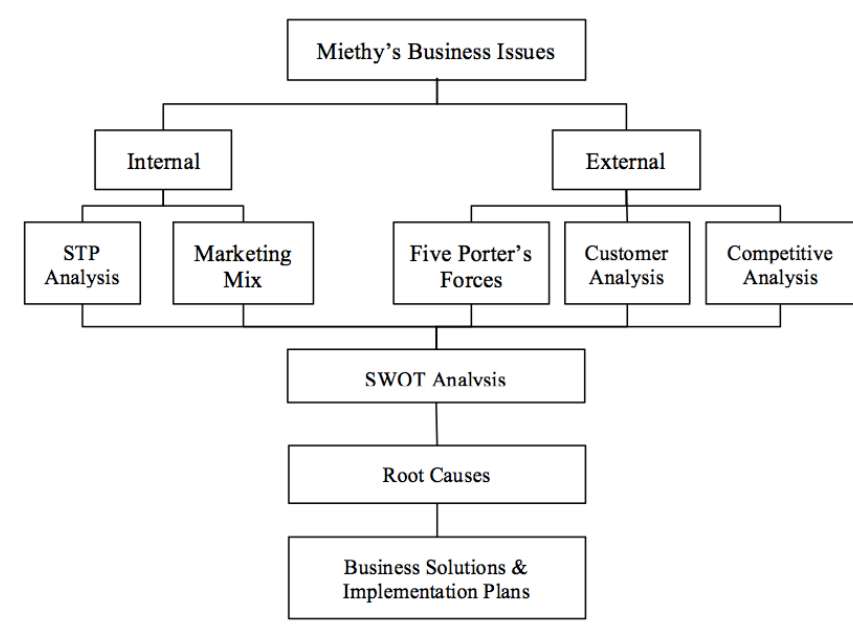

Fig. 1. Conceptual Framework of Miethy.

\section{A. Internal Analysis}

Internal analysis process is more detail when the company was determined all of the aspects. This internal analysis will conduct through Segmentation - Targeting - Positioning Analysis and Marketing Mix 4P's.

\section{1) Segmentation - Targeting - Positioning Analysis}

The Segmentation - Targeting - Positioning analysis is made up of a variety of relatively homogeneous categories, each with its own set of needs and desires. The marketers attempt to identify those market segments using this STP analysis, direct marketing activity at segments that marketers assume their business will fulfill greater than their competitors and putting their value proposition to appeal to the target market (Lynn, 2011).

Segmenting is a stage when the company identifies all customers by grouping, and it's an important issue for any business. Miethy geographic segmentations is in Indonesia, especially for a Java Island with an urban or sub-urban lifestyle. In terms of demographics segmentation, Miethy's target is 20-75 years old, for all genders who have a minimum monthly income of Rp. 5.000.000 with occupations such as a worker or retiree, housewife, college student, and health worker. In terms of psychological segmentation, Miethy targets the middle to upper social class and has an interest in a healthy lifestyle. And lastly, the behavioral segmentations are willing to give positive feedback to recommend the product that has positive benefits from Miethy products.

Targeting is necessary to conduct several surveys in order to find out the state of the market later so that the marketing process is not misdirected. For the current targeting of Miethy, we focus first on West Java and surroundings so that it is easier to reach. For the persona, we still follow from the initial segmentation, there are women and men from 23 until 55 years old who have an interest in a healthy lifestyle, and middle to upper social class.

A successful positioning is being able to identify different and appropriate competitive advantages so that they choose the right strategy [4]. After 5 months of Miethy's launched and while determining the customer segmentation, Miethy must provide a good positioning in the minds of the target market. Miethy is in the upper right position of the chart. This position was Miethy on the superiority of high product quality for the middle-upper social class.

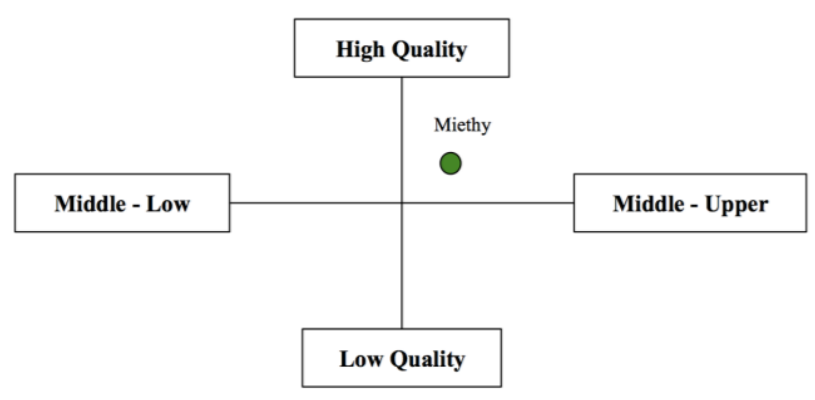

Fig. 2. Miethy's Positioning.

\section{2) Marketing Mix 4P's}

Marketing mix is a set of marketing tools for the company to implement its marketing strategy that can be used to communicate with customer targets and classified into four board kinds of activities: product, price, place, promotion (Kotler P \& Amstrong, 2016).

Miethy's product is healthy noodles made from high quality almond flour, without preservatives, with two variant products; original and vegetable (that has the added essence of vegetables). Miethy's products are low-calories and lowfat, high fiber, and also gluten free which makes our products safe for people with chronic diseases who must consume low-sugar foods.

Miethy offers a fairly high price compared to the price of instant noodles circulating in Indonesia. Miethy chooses a product sales policy by "the more products you buy, the more economical the price you pay". Therefore, buying 3 pieces of products is more efficient than buying only 1 piece of product.

TABLE I: MIETHY'S PRICE LIST

\begin{tabular}{cc}
\hline \hline Product & Price \\
\hline $1 \mathrm{pcs}$ & Rp. 35.000 \\
$2 \mathrm{pcs}$ & Rp. 60.000 \\
$3 \mathrm{pcs}$ & Rp. 75.000 \\
\hline \hline
\end{tabular}


Miethy is a homemade healthy food online business based in Bandung, Indonesia. Currently, its sales channel is only by social media with pre-ordered buying system. Miethy promotion activities have endorsed an influencer who lives a healthy lifestyle. The results of this promotion activities is increasing the number of followers on Miethy's Instagram, however there were no transactions occurred. This does not create a positive value for sales of Miethy products. Therefore, it is also seen from the engagement rate value of Miethy's social media accounts, especially on Instagram. The engagement rate of Miethy Instagram result is $0.95 \%$, this is very far from the value that should be as much as $8 \%$ for the number of 1000-5000 followers. And the performance of Intagram content was decreased.

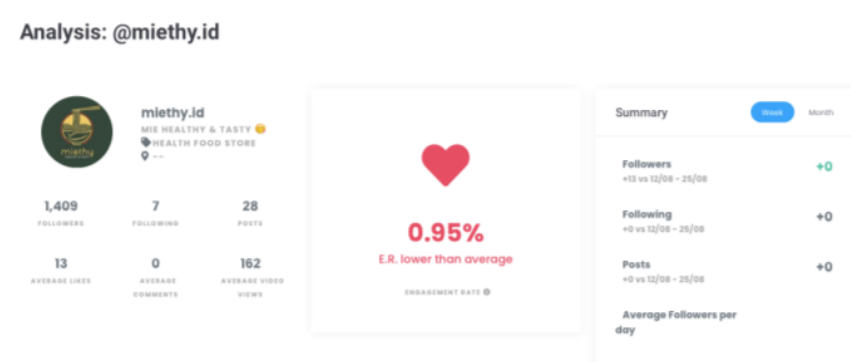

Fig. 3. Miethy's Instagram Engagement Rate.

\section{B. External Analysis}

External analysis process is more detail when the company was determined all of the aspects. This external analysis will conduct through Five Porter's Forces, Competitive Analysis and Costumer Analysis.

\section{1) Five Porter's Forces}

The Five Porter's Forces model is a framework that analyzes five forces that define a firm's competitive strategy and define the profit potential of an industry. The five important competitive factors identified by Porter's model: threat of new entrants, supplier power, buyer power, substitution threat, rivalry among existing competitors (Rothaermel, 2017).

The first factor is threats of new entrants. The result is the food and beverages industry are a business field that is easy to start and easy to leave, because with a small production scale it will cause companies to increase prices which are high and difficult to compete with larger companies. Moreover, with the Covid-19 pandemic, all food and beverage industries have to reduce costs in order to stay afloat.

The second factor is the bargaining power of supplier. Miethy has one supplier that cannot be changed, there is a supplier of almond flour, because the supplier has quality raw material nutritional components that Miethy's needs. Miethy might also seek for alternative raw materials suppliers that can provide quality and pricing that are competitive with the firm. The third factor is the bargaining power of buyer. Miethy must make customers loyal because of the quality and price of the products produced. If there is a slight change in the Miethy product, it will also have a big impact on the company. Customers are still unfamiliar with this miethy product and can still substitute other items for
Miethy products if they like, but customers have a significant impact on the sales of Miethy products.

The fourth factor is the threat of substitute product. There are still many products that offer the same value as Miethy. The public will consider all sides offered, such as price, product distribution, and others. Indeed, Miethy's price is higher than competitors' products and competitors' products can be obtained easily in various offline stores. And the result for threat of substitute product is high. And the last factor is rivalry among existing competitors. Miethy was in high competition with other competitors, but still has a chance if Miethy can build an innovation or idea that can runs fast in the future. With those analysis result, the researcher can conclude the five porter forces as follows.

TABLE II: THE FIVE PORTER'S FORCES SUMMARY

\begin{tabular}{ccc}
\hline \hline Factor & High & Low \\
\hline Threats of New Entrants & $\checkmark$ & $\checkmark$ \\
Bargaining Power of Supplier & & \\
Bargaining Power of Buyer & $\checkmark$ & \\
Threat of Substitute Product & $\checkmark$ & \\
Rivalry Among Existing & $\checkmark$ & \\
Competitors & $\checkmark$ & \\
\hline \hline
\end{tabular}

\section{2) Competitive Analysis}

The competitive analysis will be carried out by business people as a reference or main information in their business competition (Fleisher \& Schindler, 2013). Miethy has several competitors in the healthy food business: Lemonilo, Muscle Snacks, and Tim Bosan Gendut. The competitors' business that will be analyzed by the author are a business that has a varied menu of healthy food, which can be used as a main menu or just a snack. The summary of analysis is as follows.

TABLE III: THE COMPETITIVE ANALYSIS SUMMARY

\begin{tabular}{ccccc}
\hline \hline \multirow{2}{*}{ Competitor } & $\begin{array}{c}\text { Product } \\
\text { Offered }\end{array}$ & $\begin{array}{c}\text { Value } \\
\text { Offered }\end{array}$ & Price & Positioning \\
\hline \multirow{2}{*}{ Lemonilo } & Noodles & $\begin{array}{c}\text { Healthy, } \\
\text { Natural }\end{array}$ & Rp. 6.000- & Low - \\
& & Product & Rp. 9000 & Middle \\
Muscle & Snacks, & Healthy & Rp. $30.000-$ & Low - \\
Snacks & Catering & Rp. 60.000 & Middle \\
Tim Bosan & Dimsum, & Gluten & Rp. $28.500-$ & Middle - \\
Gendut & Gyoza & Free & Rp. 110.000 & Upper \\
\hline
\end{tabular}

\section{3) Customer Analysis}

Entrepreneur must know what the customer wants and needs, so that the business runs with good financial flows and there is an increase in sales This analysis was conducted by distribution of questionnaires to find out how the customer profile is suitable for Miethy's business in Indonesia. The target questionnaire is located in West Java, obtained by 67 respondents who represent in filling out the questionnaire. The question focusing on the customer benchmarck for healthy food products and considering of Miethy products with the personality targeting in willingness to recommend and pay for healthy food. From 67 respondents, there are $64.2 \%$ knew Miethy's brand and $95.8 \%$ will recommended the Miethy's product to other peoples. 
TABLE IV: THE CUSTOMER BENCHMARK ANALYSIS

\begin{tabular}{|c|c|c|c|c|}
\hline Aspect & Level 1 & Level 2 & Level 3 & Level 4 \\
\hline Brand & $\begin{array}{l}\text { Very un- } \\
\text { important }\end{array}$ & Unimportant & Important & $\begin{array}{c}\text { Very } \\
\text { important }\end{array}$ \\
\hline $\begin{array}{l}\text { Nutritional } \\
\text { composition }\end{array}$ & $\begin{array}{l}\text { Very un- } \\
\text { important }\end{array}$ & Unimportant & Important & $\begin{array}{c}\text { Very } \\
\text { important }\end{array}$ \\
\hline $\begin{array}{c}\text { Product } \\
\text { variant }\end{array}$ & $\begin{array}{l}\text { Very un- } \\
\text { important }\end{array}$ & Unimportant & Important & $\begin{array}{c}\text { Very } \\
\text { important }\end{array}$ \\
\hline Product taste & $\begin{array}{l}\text { Very un- } \\
\text { important }\end{array}$ & Unimportant & Important & $\begin{array}{c}\text { Very } \\
\text { important }\end{array}$ \\
\hline $\begin{array}{c}\text { Product } \\
\text { texture }\end{array}$ & Hard & Rather hard & $\begin{array}{l}\text { Rather } \\
\text { smooth }\end{array}$ & Smooth \\
\hline $\begin{array}{c}\text { Price for } \\
\text { healthy food }\end{array}$ & Cheapest & Less cheaper & $\begin{array}{c}\text { Little } \\
\text { expensive }\end{array}$ & $\begin{array}{c}\text { Premium } \\
\text { price / more } \\
\text { expensive }\end{array}$ \\
\hline Packaging & $\begin{array}{l}\text { Very un- } \\
\text { important }\end{array}$ & Unimportant & Important & $\begin{array}{c}\text { Very } \\
\text { important }\end{array}$ \\
\hline Promotion & $\begin{array}{l}\text { Not very } \\
\text { tempted }\end{array}$ & Not tempted & $\begin{array}{c}\text { Little } \\
\text { tempted }\end{array}$ & $\begin{array}{c}\text { Very } \\
\text { tempted }\end{array}$ \\
\hline
\end{tabular}

The results of business issue exploration will be combined to find out how current Miethy's business position and also solve problems that occur by determining a SWOT analysis strategy. Strengths and weaknesses of a business are included in internal analysis, while opportunities and threats are external analysis (Kotler \& Keller, 2012). SWOT Analysis of Miethy that concluded on table follows

TABLE V: THE SWOT'S ANALYSIS OF MIETHY

\begin{tabular}{|c|c|}
\hline 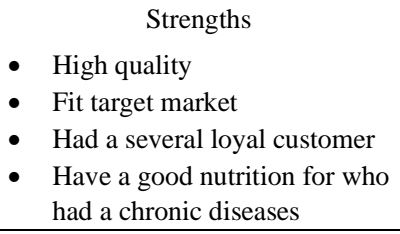 & \begin{tabular}{ll} 
& \multicolumn{1}{c}{ Weaknesses } \\
- & Less variant product \\
- & Lack of branding product \\
- & High prices range \\
- & Have not yet a legal \\
& certificate product \\
\end{tabular} \\
\hline $\begin{array}{l}\text { Opportunity } \\
\text { - Can produce variant product } \\
\text { based on customer needs } \\
\text { - } \quad \text { Raising awareness on healthy } \\
\text { food consumption } \\
\text { - Online marketplace and } \\
\text { applications is more desireable }\end{array}$ & 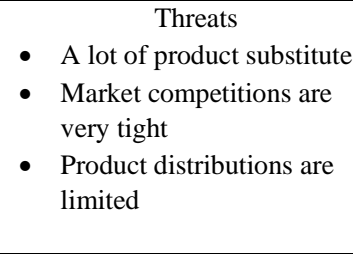 \\
\hline
\end{tabular}

\section{BUSINESS STRATEGY FORMULATION}

\section{A. Proposed a New Marketing Mix 4p's}

This new marketing mix strategy is planned based on internal data and collaborated with the results of customer analysis so that Miethy's latest products can be in accordance with customer desires and needs. Miethy will attempt to create a new type of healthy noodle that can be enjoyed at any time and easy to carry, similar like cookies or other snacks. Based on the questionnaire as well, customers prefer finished products, not going through the "pre-order" ordering process, because the level of enthusiasm for the product has not decreased. Compared to competitors, products in the form of appetizers and snacks are more preferred, because such foods can be consumed directly without being cooked first. Therefore, Miethy will try to make a plan to make a product with "Healthy Noodle Snacks".

Customers are predicted to be more excited about Miethy as a result of producing healthy noodle snacks. Product variants will be developed with various tastes. According to the Iprice article, the favorite noodle flavors for Indonesians are chicken curry and soto. And the millennial generation likes korean noodle flavor variants such as kimchi and spicy cheese (Andini, 2021). Therefore, Miethy intend to add three flavor varieties chicken curry, cheese, and spicy, which will complement the healthy noodles. The Miethy's new product will offered with affordable price range that is around Rp. 20,000 - Rp. 30,000 for each portion.

Miethy will focus in Bandung and its surroundings first. But it is possible if there are customers from outside the city of Bandung who want to buy Miethy products the team will send these Miethy new products with shipping services. And Miethy will try to change the product sales system which was previously a pre-order system into a ready product. Regarding promotions in online media and online marketplaces, Miethy will try to reactivate the online marketplace accounts; Tokopedia, Shopee and the Website. As the main social media that Miethy uses, Miethy's Instagram account will be promoted using Instagram Ads with an advertising period of at least 3 times a week. This promotion strategies are a method based on data that Instagram and online marketplaces like Shopee and Tokopedia are the most frequently opened online applications. And, other support promotion activities, that is taking a photoshoot of Miethy products (old products or new products) with the professional photographers for the culinary field.

\section{B. Proposed a New STP}

Proposed a new STP is the next solution step to develop and answer the problems that occur in Miethy. Miethy's range business will smaller than before, so that it can be controlled by the team. New segmentation it will be seen on Geographic aspect; only in West Java Indonesia (especially Bandung, Cimahi and Jabodetabek), age range is from 23 until 45 years old with minimum income Rp. 2.000.000 as a worker, housewife, college student or graduated, etc. Others Miethy's segmentation is still same with before. Miethy's targeting market is not far from the proposed segmentation. The new targeting is in area, age, occupation, and benefits (Healthy, Quality, Taste, Price, Value for Money, Easy to Bring). Miethy's positioning hasn't changed, it's still in the top right position. Miethy stay on the superiority of high product quality for the middle - upper social class.

\section{Hiring a Human Resource}

One of Miethy's problem is the lack of human labor. So that everyone has an ineffective job because each individual from the team does not focus on Miethy, divided by other activities. Therefore, by recruiting at least one employee for each division, it is possible for this Miethy business to run again without having to interfere with other activities. When hiring employees, the company must make a clear contract so as not to harm both parties.

\section{CONCLUSIONS}

Since the decline in sales in the fourth month after launching the product, the Miethy team has experienced a decline in management performance and brand performance has also not increased. With the Covid-19 pandemic, the team experienced obstacles in the movement of business.

Based on this research analysis, Miethy has many 
competitors that offer the same value, and the market competitions are very tight. Many people do not know this brand, and the company is still far from being a "top of mind" healthy food brand in Bandung. Miethy must change the business concept, especially in its 4P's marketing mix with the same value.

As a new business, Miethy's sales was fluctuated and always below its sales target. The method that will be the ideal solution from this research and can be expected to make Miethy increase sales, is the Proposed New Marketing Mix 4P's. A new marketing strategy is needed in product development and re-activating the promotional activities of Miethy product. Miethy has plans to make product variations, that is "Healthy Noodles Snacks" with three flavors: chicken curry, cheese and spicy. The price range of Rp. 20,000 until to Rp. 30,000. The sales location for Miethy's products will be focused first on the city of Bandung and its surroundings, so that sales are easy to control by team. And Miethy's promotion strategy will be optimized with digital marketing, especially on websites, social media, and online marketplaces. That New Marketing Mix 4P's will start as early as possible in 2022 with three main objectives there are Research and Development activities, Management system and Promotion activities.

\section{REFERENCES}

Andini, Fanny Nur. (2021). Trend: Produk Terbaik. Iprice Article. [Online]. Available: https://iprice.co.id/trend/produk-terbaik/indomie-sampaisamyang-ini-7-mie-instan-favorit-di-indonesia/.

Fleisher, C.S \& Schindler, P.S, Business and Competitive Analysis: Effective Application of New and Classics Method; Financial Times Press, 2013, 2nd ed.

Kotler. P., Armstrong G, Principles of Marketing; Northwestern University-Brunel University, UK, 2016, 16th ed.

Kotler, Ph., Keller, K. L. Marketing Management; Pearson International Edition, prentice Hall, 2012, 14th ed.

Lynn, M. (2011). Segmenting, Targeting and Positioning Your Market. Ecommons Edu. [Online]. Available: https://ecommons.cornell.edu/handle/1813/71546.

Novita, Stella. (December, 2018) Healthy Meals Among Indonesian Millennials. Jakpat Article. [Online]. Available: https://blog.jakpat.net/healthy-meals-among-indonesian-millennial/.

Rothaermel, Frank T, Strategic Management; United States of America, 2017, 3rd ed.

WHO. (2020). Healthy at Home. World Health Organization Article. [Online]. Available: https://www.who.int/campaigns/connecting-theworld-to-combat-coronavirus/healthyathome.

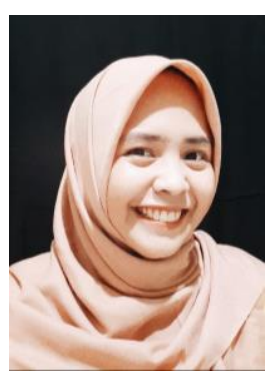

Delisa Julianita Putri, was born on July 11, 1995 in Bandung, Indonesia. Graduated from Pharmacist proffesion program at Jenderal Achmad Yani University in 2018. She continued her Master degree in Magister of Business Administration at Bandung Institute of Technology and graduated in 2022. Currently, she is a pharmacist at Kimia Farma and an entrepreneur. 